\title{
BORN-GLOBALS AND CULTURALLY PROXIMATE MARKETS
}

\section{INTRODUCTION}

High-technology is demonstrated to influence the internationalisation of born-globals (Freeman, Hutchings, Lazaris \& Zyngier 2010; Crick \& Spence 2005) in terms of rapid pace, location of overseas markets, and readiness to adopt the technology (Knight \& Cavusgil 2004). Earlier research documents the origin of born-globals from smaller, developed economies which seek out collaborative partners in markets, usually located in the larger developed economies, which are culturally proximate (Chetty \& Campbell-Hunt 2004; Chetty \& Stangl 2010; Freeman, Edwards \& Schroder 2006). While some studies argue that bornglobals prefer to access culturally proximate markets initially, to reduce the perceived risk of foreign entry for the young, inexperienced firm, others (e.g. Bell 1995; Moen \& Servais 2002) argue that they seek out opportunities wherever their networks take them. They seek or discover opportunities in larger markets which offer economies of scale and exploit them quickly before a window of opportunity closes (Freeman et al. 2010).

The literature has mixed views about whether born-global firms act in a proactive way (Oviatt \& McDougall 1994; 1997; 2005; McDougall \& Oviatt 2000; McDougall, Shane \& Oviatt 1994) or a reactive way (Sharma \& Blomstermo 2003) or both (Nordman \& Melen 2008) during their internationalisation process. Furthermore, there are contrasting views about whether born-globals are making reactive and/or proactive choices to enter culturally proximate markets. Culturally proximate (or familiar) markets are those where the psychic distance (cultural and business familiarity) (see Arenius 2005; Brewer 2007) between the home and host environment is small. The experiential model of internationalisation (Johanson \& Vahlne 1977; 2003; 2006; 2009) explains an initial preference by firms for culturally proximate markets because of inexperience and reduced risk, suggesting a reactive and 
incremental approach (Nordman \& Melen 2008). Other studies (e.g. Hutzschenreuter \& Voll 2008), however, suggest more proactive reasons for firms' initial choices of culturally proximate markets.

Born-globals operate in dynamic markets where the windows of opportunity open and close rapidly. Their very survival and success is determined by how quickly, efficiently and holistically they anticipate, and then act upon, foreign opportunities (Nordman \& Melen 2008). Unlike older firms, born-globals face unique challenges in discovering and exploiting foreign market opportunities, because of their short history, lack of resources and accelerated pace of internationalisation (Freeman et al. 2006). Research suggests that how these activities are managed requires further investigation. Nordman and Melen (2008) draw a distinction between two kinds of knowledge available to internationalising firms, namely, international knowledge and technological knowledge. While the incremental approach to internationalisation emphasises the importance of international knowledge (Johanson 1977; 2006), the born-global approach emphasises the importance of technological knowledge for internationalisation (Nordman \& Melen 2008; Zahra, Ireland \& Hitt 2000). Hence, we use this distinction to compare the relevance of these two types of knowledge for born-globals and older firms.

Consequently, the purpose of this paper is to make two comparisons between bornglobals versus older firms. First, whether factors such as cultural proximity, international and technological knowledge are more important in born-globals than older firms. Second, whether born-global and older firms are proactive or reactive in their choice of culturally proximate markets. We employ an abductive approach (Dubois and Gadde 2002) in our study by using the literature to develop introductory research propositions that compare bornglobals and older firms. We then move back and forth between the data and theory to revise and extend the introductory propositions. 
In the next section we review internationalisation theories to highlight the differences between older firms and born-globals with reference to culturally proximate markets. The research method is then outlined. This is followed by the findings and discussion based on analysis of twenty Australian born-global and older firms. Finally, conclusions, theoretical contributions, managerial implications, and issues for future research are given.

\section{INTERNATIONALISATION MODEL， KNOWLEDGE-BASED VIEW AND NETWORK APPROACH}

The internationalisation process entailing a gradual step-by-step commitment to sell and manufacture internationally as part of growth and experiential learning is often referred to as the Uppsala model (Johanson \& Wiedersheim-Paul 1975; Johanson \& Vahlne 1977). This internationalisation model and its authors' subsequent revisions (2003; 2006; 2009) have come under increasing criticism. Reid (1983) argues it is too deterministic and general, because the firm's choices of entry and expansion modes are more selective and context specific, explained by heterogeneous resource patterns and market opportunities, which Johanson and Vahlne (1977) actually envisaged but did not explain. The network approach and internationalisation model stress the cumulative, experiential nature of firm activities. The term networks, as used in this article, means the relationships a firm has with its customers, suppliers, competitors, government and educational institutions (Johanson \& Mattsson 1988). The internationalisation model focuses on the internal development of firm knowledge and other resources, which the network approach also offers as a model of the market and the firm's relations to that market. We argue that closer theoretical examination and integration of networks and knowledge will serve to increase understanding about the internationalisation of firms: first, with respect to network internationalisation processes; and second in the use of market assets such as knowledge in international competition, especially as understood by the 
Knowledge-based view (KBV) (Barney 1991; Grant 1996). The KBV perceives organisations as repositories of knowledge and competencies. It is well documented as applying to studies on smaller born-global internationalisation (Autio 2005; Johanson \& Vahlne 2003).

\section{INTERNATIONALISATION AND CULTURAL PROXIMITY}

Petersen, Pedersen and Lyles (2008, p.1097) argue that "entering foreign markets requires a knowledge development process, and the entering firm may realize a considerable market discrepancy, that is, the firm identifies a gap between the knowledge possessed and the knowledge needed for accomplishing the foreign business venture", yet they say few studies focus on how firms reduce 'the knowledge gap'. One area in which internationalising firms may reduce the knowledge gap, as well as decrease the 'tolerable risk', is by entering into culturally proximate markets.

Johanson and Wiedersheim-Paul (1975) introduced the concept of psychic distance to explain why firms avoided uncertainty during internationalisation by initially entering markets that were similar to their own, for example in respect to the economic, cultural and institutional environment. They proposed that as these firms gained experience in international markets they gradually moved to more psychically distant markets. In their revised 2009 internationalisation model Johanson and Vahlne argue that it is being outside the network that creates more uncertainty than psychic distance. Instead of the term psychic distance we use the term cultural proximity in our paper as it emphasises cultural and business familiarity, our focus, and the key components emphasized in Brewer's (2007) multidimension index for psychic distance. Chetty and Campbell-Hunt (2004) found that it is still important for born-globals to enter culturally proximate markets for their initial foreign

market entry. They found, however, that once born-globals start their internationalisation process, they quickly enter other culturally distant markets worldwide. Studies in the software 
industry, where born-globals predominate, have mixed results about the importance of cultural proximity. Chetty and Stangl (2010) in their study of New Zealand software firms found that culturally proximate markets are important for both born-globals and firms that internationalise incrementally. They found that since born-globals have existing networks and work experience in culturally proximate markets they tend to enter these markets first. The main initial markets for these New Zealand firms were Australia, USA and the United Kingdom as all of these markets have close cultural proximity to New Zealand. However, Bell (1995) in his study of the software industry, found that domestic and foreign clients, a niche market strategy and industry specific factors determined the small firm's internationalisation process rather than cultural proximity. Similarly, Majkard and Sharma (1998) found that in software firms it is the actual software that determines their rapid internationalisation. They found that these born-globals enter initial foreign markets based on software usage characteristics rather than markets that are culturally proximate.

\section{LEVEL OF INTERNATIONAL KNOWLEDGE}

Nordman and Melen (2008) refer to the KBV in suggesting both international and technological knowledge influence born-globals to discover and exploit new opportunities. "International knowledge is a broad concept, encompassing specific international industry and marketing experience” (p. 173). They argue that international knowledge is "...as knowledge about managing various relationships with foreign counterparts", and that this "knowledge" is "defined" as "experiential knowledge about conducting business activities within an international setting" (p. 173). Johanson and Vahlne (2009 p. 1405) describe internationalisation knowledge as follows; “...that is knowledge that reflects a firm's resources and its capabilities for doing international business". Nordman and Melen (2008) define technological knowledge as "experiential knowledge about the technology upon which 
a firm's products are built” (p. 173). Autio (2005) argues international knowledge possessed by the managers prior to inception of the firm is especially important to born-globals because they lack organisational history, and thus individual-level knowledge exists prior to firm-level knowledge. Prior international managerial experience within born-globals drives internationalisation (Knight \& Cavusgil 2004). Compared to firms that internationalise as described within the incremental internationalisation model (Johanson \& Vahlne 1977) bornglobals have substantially more international market experience (McDougall et al. 1994; Madsen \& Servais 1997). Chetty and Campbell-Hunt (2004) found that born-globals have more international experience than firms who start internationalising incrementally. They have previous international experience because managers have worked abroad or for other multinationals before establishing their own companies. Internal resources, namely personal networks/inside and outside connections and activities provide born-globals with valuable, non-imitable resources for internationalisation, such as business advice and opportunities in early inception (Chetty \& Campbell-Hunt 2004). While previous studies support the primary importance of managers in the initial internationalisation process of born-globals, they fail to consider whether it is international or technological knowledge that primarily guides managers' early decision-making.

\section{LEVEL OF TECHNOLOGICAL KNOWLEDGE}

Numerous studies confirm the considerable number of born-globals that operate in high-technology industries, where the founders and managers possess high level technological knowledge (Freeman et al. 2010; 2006; Freeman \& Cavusgil 2007; Rialp, Rialp \& Knight 2005). Nordman and Melen (2008) define "technological knowledge" as "experiential knowledge about the technology upon which a firm's products are built" (p. 173). They "regard this knowledge to be purely technological and, thus, devoid of any business element" 
(p. 173). They argue that this is "therefore", why they "use technological knowledge to capture the experiential knowledge about technological issues connected to the founders and managers of Born Global firms" (p. 173) in their study of this type of firm.

Studies suggest born-global managers rely on this sophisticated technical knowledge (Knight \& Cavusgil 2005), which captures experiential knowledge about various technological issues (Nordman \& Melen 2008) embedded in the personal network ties and networks of managers within firms (Freeman \& Cavusgil 2007). This is explained by resource commitments to foreign markets based on the development of mutual relationships, which incorporate learning about each other through collaborative partnerships (Johanson \& Vahlne 2003). Chetty and Campbell-Hunt (2003, p.6) argue that irrespective of what drives their initial foreign location choice, born-globals exhibit the "internationalization dimension of cooperating with business partners in both the domestic and international market". Freeman et al. (2010) dispute the importance of international knowledge, positing that technological knowledge is the driver for partner selection and that international location is an outcome of these personal network ties for born-globals. They argue that born-global managers, unlike older firms, face the pressure of establishing a revenue stream (cash flow), quickly, because of their lack of resources, and frequent high $R \& D$ expenses. This situation puts pressure on the smaller firm to commercialise their products/processes ahead of their competitors, in markets ready to adopt their technology. Thus, greater understanding is needed of the opportunity discovery and exploitation process, where knowledge development and commitment are simultaneous.

\section{PROACTIVE OR REACTIVE BEHAVIOUR}

Many studies focus on the proactive behaviour of born-globals in discovering new foreign market opportunities and acting on them quickly (Madsen 1997; Nordman \& Melen 
2008; Oviatt and McDougall 1994). However, the Uppsala model regards the discovery of opportunity as a reactive process because they say a discovery cannot be planned as an active search (Johanson \& Vahlne 1977; 2003), i.e. they refer to consequence of chance. This process, some argue, cannot be controlled and so cannot be planned by entrepreneurs, and thus more appropriately explained by entrepreneurship research (Bouchikhi 1993). It is posited that some companies are proactively choosing to avoid markets deemed culturally unfamiliar. Hutzschenreuter and Voll (2008) argue that the performance impact of cultural unfamiliarity on profitability in the MNE's expansion path is significant "and those that expand in culturally distant countries in an irregular fashion, that is, with a higher variability, will be less profitable" (p.53).

Evaluation of market opportunities, especially in turbulent policy environments, is a critical and direct influence on foreign market entry and exit. Barkema and Drogendijk (2007, p.1132) argue that MNEs enter either incrementally "or by taking steps that may result in lower initial performance but, through learning and experience, lead to increased performance in future expansions". Chetty and Campbell-Hunt (2003, p.5) suggest "that the speed of international success can be a destabilizing factor"; a view supported by Barkema and Drogendijk (2007, p.1132) who found that "expansion steps may be too large, thereby limiting the exploration of foreign market opportunities". Supporting the Uppsala model, they confirm sequential internationalisation strategies still matter - larger MNEs must "balance exploration and exploitation in internationalisation" (Barkema \& Drogendijk 2007, p. 1132).

Freeman and Cavusgil (2007) provide a typology of four managerial mindsets in smaller born-globals, partially explained by entrepreneurial practices - some are proactive, while others are more reactive in nature. In contrast to an incremental approach, they offer a theoretical explanation that integrates the Network Perspective and RBV with International Entrepreneurship. They argue that born-globals can operate both reactively and proactively 
simultaneously, depending upon the type of state of mind of the manager. Their exploration of the managerial mindset of these smaller born-global firms leads to identification of four states of commitment to accelerated internationalization by top management. They argue that delineating these states should assist managers in achieving their accelerated internationalization objectives. Any of the four attitudinal mindsets will facilitate internationalization, but the Strategist state adopts a proactive, more benevolent, collaborative behavioural stance designed to preserve key relationships. It also avoids the more reactive, short-term orientation, competitiveness, and self-interest of the Responder, the Opportunist and the Experimentalist. Movement between the various states of mind by top management across foreign markets or within existing markets is possible, including simultaneous mindsets, as they argue that the state of mind of top management is not stage determined but attitudinally driven.

Similarly, Nordman and Melen (2008) suggest that within born-globals their founders' and managers' discoveries of new opportunities are also reflective of proactive behaviour, which they describe as search activities and reactive behaviour as ongoing interactions with individuals in a specific foreign market. Nordman and Melen (2008, p.175) "perceive opportunity search activites as activities performed by Born Globals that know what is missing and how it can be found. These types of activites can be planned in advance”.

However, other "opportunities that are discovered within ongoing foreign market activities are a consequence of chance rather than planned activities" (Nordman \& Melen 2008, p. 175). In their study of eight born-global firms from Sweden, two subgroups emerged. Born Industrialist were firms started and initially managed by individuals who possessed experiential knowledge characterized as high in technological and international knowledge. However, in contrast, Born Academics were founded and initially managed by individuals with experiential knowledge which was high in technological but low in international 
knowledge. Born Industrials followed a specific internationalization strategy with focused searches to better position themselves to exploit foreign market opportunities available in target markets. Thus they decided in advance on the objective of their searches, how the activities would be formed, even before they began selling their high-technology products/processes. Thus, the Born Industrialist "uses search activities to find foreign market opportunities" (Nordman \& Melen 2008, p. 179), described as "proactive" (p. 175).

On the other hand, Born Academics exhibited little clear or settled objectives of either markets or target customers, suggesting no specific strategy. They are thus described by Nordman and Melen (2008) as a born-global that "uses ongoing foreign market activities to find foreign market opportunities" (p. 180) and are "reactive" (p. 175) in their behaviour. Chance is something that cannot be controlled, "and, consequently, planned" (p. 175). To decide whether born-globals" "discoveries are driven by proactive or reactive behaviour, we argue that search activities reflect proactive behaviour, where as ongoing interactions with individuals in a specific foreign market reflect reactive behaviour" (p. 175).

Yet Nordman and Melen (2008) suggest that the behaviours are separate and that proactiveness is primarily driven by the high level of international experience of the managers. While Chetty and Campbell-Hunt (2003) see internationalisation pace as determined by networks and level of prior international experience, they do not explain the meaning of proactiveness, but suggest managers are proactive. We question Petersen et al. (2008) who suggest that searching new opportunities is limited by born-global managers' current stock of knowledge. We posit that absorptive capacity (recognition, adaptation and use of new knowledge) in the form of technological, not international, knowledge drives their early proactive, risk-taking behaviour (Freeman et al. 2010; Oviatt \& McDougall 1994). This attitude directly impacts their internationalisation pace. 


\section{DEFINITION OF TERMS USED IN THIS STUDY AND INTRODUCTORY PROPOSITIONS}

Within this research we identify three comparative issues relating to internationalisation and cultural proximity: born-global versus older firms; proactive versus reactive behaviour; and international versus technological knowledge, which are defined in detail below.

Born-global versus older firms. The born-global literature has defined the time it takes a firm to internationalise from inception in various ways. It differs on how quickly and in how many markets a firm must internationalise in order to be considered a born-global. Research defines the time from inception to internationalisation of firms as ranging from two years (McKinsey \& Co. 1993; Chetty \& Campbell-Hunt 2004), to three years (Servais, Madsen \& Rasmussen 2007), to six years (Zahra, Ireland, \& Hitt 2000), to eight years (McDougall Shane \& Oviatt 1994). There is also variability in the literature on the proportion of international sales that can be used to define a firm as a born-global. The international sales range from $80 \%$ in world-wide markets (Chetty \& Campbell-Hunt 2004), to 75\% within two years of inception (McKinsey \& Co. 1993), to over 50\% of sales outside home continent (Luostarinen \& Gabrielsson 2006), to $25 \%$ within a few years of inception (Knight \& Cavusgil 1996; Servais, Madsen \& Rasmussen 2007). In our study we define born-globals as firms entering their initial 'host' market within 3 years from inception and older firms as those who entered after 6 years or more with much overseas foreign direct investment (FDI) experience.

Proactive versus reactive behaviour. The term proactive means that the firm actively searches international market opportunities (Moen \& Servais 2002). Nordman and Melen (2008) suggest “...that a discovery happens in a situation of unknown ignorance when an entrepreneur is not aware what information is missing...accompanied by an element of 
surprise...In contrast, a search can be undertaken for something that the entrepreneur knows is missing...[and] not followed by a surprise" (Nordman \& Melen 2008). For example, the firm actively plans and seeks new customers from a culturally proximate market. The term reactive means that the firm responds to an opportunity that is triggered by someone outside the firm such as pressure from a customer to enter a new market (Agndal \& Chetty 2007). Reactive behaviour also rests on the assumption that older firms in principle follow the traditional Uppsala model (Johanson \& Wiedersheim-Paul 1975; Johanson \& Vahlne 1977) of internationalisation, most applicable in their early stages of international commitment.

Another example of a reactive approach could be an unsolicited order from a potential customer in a culturally proximate market. Nordman and Melen (2008) refer to reactive as opportunities that are discovered within ongoing interactions that involve others in a foreign market.

International versus Technological knowledge. We use Nordman and Melen's (2008) definition of these two types of knowledge. They define international knowledge as, "experiential knowledge about conducting business within an international setting. Technological knowledge is defined as experiential knowledge about the technology upon which a firm's products are built. We regard this knowledge to be purely technological and, thus, devoid of any business element” (p. 173).

We use the above discussion from the extant literature to suggest the following introductory propositions to compare and contrast born-globals and older firms:

Proposition 1: International knowledge is important in the internationalisation of older firms and they are more likely than born-globals to be reactive in their choice of culturally proximate markets. 
Proposition 2: A combination of international and technological knowledge is important in the internationalisation of born-globals and they are more likely than older firms to utilise proactive as well as reactive approaches in their choice of culturally proximate markets.

\section{METHOD}

The use of case studies in seeking to explain firm internationalisation is increasing (Arenius 2005) and has been used in recent studies of small firm accelerated internationalisation (Nordman \& Melen 2008; Knight \& Cavusgil 2005). Case studies are most appropriate where there "...is a clear need for deep understanding, local contextualization, causal inference, and exposing the points of view of the people under study" and particularly in studies which focus on industry sectors which incorporate high-tech firms and how they "...gain access to the know-how, technologies, and capabilities" (Schweizer 2005, p. 1055). We used Eisenhardt's (1989) multiple case study approach in selecting twenty cases for this study. This allowed for cross-case comparisons and in-depth examinations between born-global and older firms with respect to their early internationalisation processes, and to corroborate findings. We followed the abductive approach (Dubois \& Gadde 2002) in this study by using the literature to suggest two introductory propositions. We then continuously moved back and forth between the data and theory to help us interpret our findings and to revise and develop concluding propositions.

Selection of firms was based on their capacity to generate information, ensuring that the research question was answered. We selected a sample of 20 firms as multiple firms provide more robustness in the analysis according to Yin (2003). The firms were sourced from the Australian-based UK Trade and Investment (UKT\&I) database, on the basis of age, size and industry (knowledge intensive and high-technology) to provide a broad spectrum of 
internationalising Australian MNEs. The UKT\&I database comprised approximately 100 Australian firms involved in FDI in the UK. All 100 firms were initially contacted by email and telephone to seek their involvement in the research. Approximately one third of the firms on the database were no longer trading. Another third did not respond to several attempts to arrange an interview with senior management, consistent with other recent studies using case study approaches, where firms will "...decline[d] participation because of company policy and time pressure" (Schweizer 2005, p. 1055). The remaining third agreed to participate in interviews; of which only 20 firms finally had senior managers available and willing to be interviewed. The final 20 firms were divided into born-global and older firms based on our earlier definitions and their details are summarised in Appendix C.

The UK was selected as culturally proximate to Australia as it is ranked least distant in a psychic distance index developed by Brewer (2007). Firm types included: born-globals (entering their initial 'host' market within 3 years from inception) and older firms (entered after 6 years or more with much overseas FDI experience). Interviews were arranged with senior managers (CEO, Managing Director, Founder), who were the key decision-makers and had first-hand experience of entry into the UK and were judged to be the most appropriate to interview given their strategic role in the organisation. A total of 23 semi-structured interviews were conducted with senior management from the 20 firms. Cases D, O, and R were identified as having two senior managers each, with direct knowledge of the firms' internationalisation into the UK who were willing and available to be interviewed. For this reason these three cases had multiple informants interviewed. See Appendices A and B for a description of the cases, industries, firm size, sales and year they entered the UK, for bornglobal and older firms, respectively; and Appendix C for analytical information on history of entry mode, initial/subsequent foreign markets and role of interviewees. 
Consistent with Schweizer (2005, p. 1055), the current study “...used semistructured interviews with company representatives to both obtain an appropriate degree of comparability and allow ample opportunity for unobstructured narration". Semi-structured face-to-face interviews (ranging from 45 minutes to 4 hours duration), were conducted in 2007-2008 in both Australia and the UK. In some instances telephone interviews were utilised where informants were repeatedly unavailable for a face-to-face interview because of travel commitments. The study used open-ended questions, following the principles of Yin (2003) and Schweizer (2005). The interview questions were initially adapted from Knight and Cavusgil (2005) and adjusted specifically for the purpose of this study.

Interviews covered the initial internationalisation process, success factors, technology orientation and international strategic approaches, the major events for the firm since its founding, and how the firm became involved in international markets. Interviews were recorded and transcribed and, to reduce subjective bias consistent with common method, triangulation of results was achieved by cross-checking factual information from interviews against secondary sources, including annual reports, company websites, industry journals and newspaper articles. Sources were compiled into a company database which recorded a comprehensive history of internationalisation.

Consistent with Yin (2003) and Schweizer (2005, pp.1055-1056), because of the qualitative nature of the data sought in the current study, triangulation was an "important means of increasing construct validity and substantive findings and subsequent propositions". The case-study database included archival documents as secondary sources together with comprehensive case write-ups and interview notes, all of which were used in the analyses. The issue of internal validity was managed by "...conducting multiple iterations...during the analyses" (Schweizer 2005, p. 1058) and using an abductive approach consistent with Dubois and Gadde (2002) as outlined in detail below. The concerns with reliability were addressed by 
“...drawing up detailed case study protocols and by following the required documentation and transcription standards" consistent with Schweizer (2005, p. 1058). The external validity of the study was "increased by studying multiple companies and analyzing comparative findings" consistent with Schweizer (2005, p. 1058), as well as Yin (2003) and Eisenhardt (1989).

The qualitative analysis employed a process of interpreting our data, by moving continually back and forth from the data to conceptual development of the research. This reflective process helped inform each re-reading of the data. This interactive process was critical to seeing how each theme was emerging, as a part of a deeply reflective and active approach to our data sorting and categorisation. We followed an abductive approach (Dubois \& Gadde 2002), as mentioned above. We used the literature to suggest Propositions 1 and 2. As part of an interactive and reflective approach we then continuously moved back and forth between the data and theory to help us interpret our findings and to develop concluding propositions and the process included data reduction (selecting, summarising and coding), drawing conclusions and verification, within and across the cases for the two groups of firms (see Miles \& Huberman 1994; Sekaran 2000). Manually coded data analysis was conducted, taking a reduction and interpretation approach based on first-level coding start-lists. From here, the collected data was divided into clusters of topics which resulted in key themes (see Miles \& Huberman 1994; Sekaran 2000). Formative indicators (factors) identified in the analysis were combined to build the dimensions that provided a comprehensive understanding of discovery/ exploitation of foreign market opportunities; and use of reactive/proactive behaviour by managers and specifically why, initially, they access culturally proximate markets.

In particular, a number of techniques were used in the analysis of data, consistent with other cases studies on born-globals (Freeman et al. 2006; Freeman \& Cavusgil 2007), 
including the use of open, axial and selective coding (Strauss \& Corbin 1990). Codes were assigned to significant sentences or phrases of the interview transcripts in order to provide emphasis under the areas of focus for our paper. Open coding required the data to be dissected for similarities and differences with no initial preconceptions. Similar concepts were grouped together with the objective of reducing the data into initial categories. Axial coding required linking of categories and sub-categories to integrate categories to develop common themes. In selective coding, integration of all the categories in previous coding stages occurred around a 'core' category. The core categories were then integrated with theoretical perspectives, including pattern-matching (Yin 2003). Thus, the analysis included open, axial, and selective coding to develop the descriptive narrative and final link to theory about the central phenomenon of our paper - senior managers' understanding of their behaviour (reactive and proactive) and use of knowledge (international and technological) in the process of early internationalisation of their firm. Analysis in the selective coding stage utilized a theorybuilding focus for the ultimate development of concluding propositions, developed from the findings and informed by re-visiting the literature as part of the overall abductive process adopted for our study. The concluding propositions, which emerged from the findings, were then integrated with theory in the discussion, consistent with a theory-building approach to analysis outlined by Yin (2003) and Dubois and Gadde (2002).

\section{FINDINGS - SELECTING THE CULTURALLY PROXIMATE MARKET}

In the development of themes and sub-themes (elements and dimensions), data which are derived from the cases provides illustrative examples which are used to build a story or holistic summary around the use of proactive vs reactive behaviour and use of technological vs international knowledge. Analytical generalisations are generated through our cases. In some situations, a theme may be developed based on a single case, while other themes may 
involve one or more cases, as each part of the story unfolds, in an holistic and abductive approach to data analysis and theme generation. The cross-case analysis presents the most significant and illustrative examples, rather than a description of every case for each category, theme and sub-theme. Where cases were indicative or did add value to the development of the argument/themes they have been indicated in the findings section. Through an interactive process of re-reading and re-sorting themes/sub-themes, and moving back and forth between the literature and the data, a final set of themes is presented below. We begin the data analysis with the perceptions of born-global managers, followed by older firm managers.

\section{Born-Global Firms}

A Stepping Stone into Key Western Lead Markets: For smaller born-globals in the innovative product manufacturing sectors, such as sustainable production, Germany is considered to be the lead market in Europe. While the UK is culturally preferred as an initial market as illustrated by Cases $A, E$ and $G$, Germany is repeatedly selected for long-term repeat investment with the intention of making it the home base. Germany is perceived as having a sympathetic attitude to government funding for innovative high-tech MNE manufacturers. Many of the bigger global brands are also situated in the market, making it a very attractive location for manufacturing MNEs. In addition, being a lead market, Germany attracts many of the supporting industries around high-tech innovative manufacturing, leading to further synergies. From this German base, firms expect that Central and Eastern Europe (CEE) will be developed for further manufacturing and sales opportunities. Lower cost is the motivation for country selection in CEE, and FDI with wholly owned subsidiary (WOS) preferred over low equity modes, for example exporting, to maintain control over processes. Existing distributors in CEE will be used to support the born-global's further manufacturing 
bases in the region, providing ultimately for a fully integrated Western and CEE manufacturing and supply chain operation, as revealed in Case E.

I think ultimately Germany will probably be our base...for expansion into Eastern Europe...actually finding... a lot of the brand owners are pushing production into low cost .. you end up with the major brand owners might put a footprint down for a factory... the converters and all of the support industries then get close by because it's not efficient to be travelling more than typically $200-300 \mathrm{~km}$ away from the place that you're doing business. So you get a lot of regionalized activity so you need to be moving in that direction...There are lower cost countries than those [Eastern Europe], yes. But lot further out. You don't have to go to those countries [Central and Eastern Europe] to be low cost...You know there's still a close proximity because the consumer market is not changing. Germany ain't moving anywhere!... the industries are not going to move so far away that it's inefficient to get materials into them. What they're going to do is move into adjacent markets which are more efficient...It's completely logical and that's what we're actually finding (Case E).

In addition, we observe from Case $A$ (and supported by Cases $C, D$ and $H$ ) that many born-globals have associations with other business entities because of their habit of frequently setting up a new business fully independent of the parent group of companies, described as a 'spin off' process. These contacts can be used to build connections in the UK, where they locate the base for ease of access to other lead markets in Western Europe. Familiarity with the culture and language, and association with other Australian MNEs in the UK does provide an easy platform for born-globals to enter and manage subsequent expansion into Europe through exporting from the UK location.

You know none of us believe that you should do the typical Aussie thing and base everything in London because our products weren't going to be sold in London for ages because the National Health were very conservative and they are short of money...there was no point from a market point of view being in the UK and perhaps if I had been multi-lingual I wouldn't have done it but to feel a bit more personally comfortable and again a sister company gave me some office space in London. I wasn't there all that much because I was on the road most of the time, mostly not in the UK. ...So I chose London to be at home and because it had convenient flights everywhere and at a reasonable cost and that there was no single market actually that would take off before any other so I had to be in lots of countries so I may as well be here. But that doesn't mean that that's where I ultimately set up the company it just means where I was personally was located and then made a decision still where to set up the company... While I figured it out, I was based in London! (Case A).

The UK is widely viewed as resistant to outsiders in medical technologies. While it is preferred for location initially (e.g. manufacturing, sales office), this is based around easy familiarity and not expectations of high growth, despite its large population. 
Historic Links: The UK also has strong historic links with the Middle East (ME), and we observe through Case $H$ (supported by Case B) that many born-globals receive client calls, from the ME, because they are regularly in touch with the UK, which they respond to, described as client following. The links are with local organisations in the ME as well as UKbased MNEs in the ME.

We entered Dubai about four years ago and found that very successful. Once again, that was based on a project opportunity that a client presented us with [in the UK]... We had a similar opportunity with a client of ours which is Hyatt International. Obviously they're a global operation and we had the intent as an international organisation to enter Europe but we were looking for the right opportunities presented... from over here and find an office, then go and look for the project of the first job. So we wanted the job to come first and that opportunity came in the middle of 2005 but I don't think it was a specific business plan objective with a date on it with an objective to if an opportunity in Europe came along we definitely would look at it but it had to come along generally to us rather than us to specifically pursue it (Case H).

Thus, the UK provides industry links not only to Europe but also to the ME, such as IT project management services in the construction industry. These connections provide linkages to players in the ME and assist in identifying further market entry opportunities. While the UK is perceived as a strategic market in Europe, the ME is seen as a high growth market offering very lucrative returns in Asia, and it is possible to build leads through the UK to this market. In addition, as many high-tech born-globals must have the infrastructure available for an IT platform, the ME, being a highly advanced market, is regarded as an ideal location, complementing their presence in the UK base. It is important for these firms providing hightech IT transfer systems to be located in both the UK and ME as the home market is seen as far behind and not offering comparable growth.

Other Culturally Proximate Markets: The UK is a large market, frequently seen as easier to penetrate than the US, another culturally proximate market, according to Case F (supported by Case B). Just adopting an attitude of 'having a go' seems to provide the opportunity for clients to be located.

I don't know whether this is showing naivety or not but we didn't really go out there and go, "This is going to be hard" we just went out there and said, "Okay, we've got to crack the UK market, how do we go and do it?" We didn't really assess what would be easier, what would be harder, what's going 
to be a difficulty...the process, it was very serendipitous. I suppose in looking back if I had to do it in hindsight, it was probably easier than expected to get Unilever for example or something like that. But if you look at the US market and our attempt over there, my answer to that would be, "It's been harder than I expected to actually get a client". I would have thought we would have signed one up by now. It's been harder to manage. It's funny the time differences is just slightly different in the US than everything else...(Case F).

Expansion also requires a great deal of determination from smaller born-globals in the professional services. In Case A we observe that high-tech firms are spending considerable time and effort researching, prior to market entry, to locate key international markets. For high-tech innovative firms which have a niche, there may not be significant direct competition (supported by $B, C$ and $D$ ). Yet, correctly selecting key markets for initial entry is regarded as highly important to their rapid growth. Limited financial resources often make it necessary for small to medium-sized born-globals to select a single market initially, revealed by Cases $A$ and $H$. We observe for newer born-globals the constant need to generate cash flow through sales in each market location, which is frequently used to gauge whether to enter immediately, or to leave a particular market for a future time when sales are likely to be easier to secure because of the stage of development of the market.

Well Eastern Europe has got broadband. Eastern Europe, the markets individually for each country aren't as big. I mean France, Germany and Italy are big markets. Yes, we're kind of tossing up at the moment between Western Europe and Eastern Europe. Or do we continue going in other markets in the Middle East so at any one point in time we have to be going, given our limited resources, where is the best place to put it? Are we better off putting more in existing markets or if we're opening up new markets, which markets should they be?... if they don't start generating revenue, say, in nine months then we'd consider closing it down... (Case H).

This usually means born-globals initially need to follow an existing client into the new market. Thus the stage of development of the market and an existing client are observed to be necessary conditions for market entry for the smaller born-globals in the first few years. We observe that referrals from existing customers in other markets are actively used for connections to assist entry into successive markets.

Well, we won't go in there unless we have a customer to go in there for so up until that point we will be looking for customers, looking for flying people in, having meetings with potential customers...It's a combination of referrals from existing customers, cold calls for new business, marketing to try and raise awareness, a combination of all those things (Case $H$ ). 
This is a difficult choice because the initial market needs to provide a quick cash flow (revenue stream), given high R\&D start-up costs, as well as enable a high level of recognition following entry into the international market. Thus, the market selection criteria used by these firms suggests that while they do select the UK as an initial market, it is not primarily because of large growth potential or securing government grants (unlike the US). It is due to familiarity (business, culture and language), which is understood to make it easier to locate customers in the UK and then use this as a base for locating or following customers into nearby markets, which offer greater potential for timely sales. If they cannot establish sales in less than 12 months in the new market they may well leave and seek out other markets in the region, by following clients.

Chance: Chance (not planned) activities can play a role in the decision to locate in one market over another, supported by all born-global cases $(A, B, C, D, F, G$ and $H$ ). For some smaller firms, such as Case $F$, chance opportunities are frequently acted upon. In one example, a co-founder wanted to take time out to develop some new product ideas and wanted to spend time in the UK.

There was a bit of luck really, to be honest. I mean we're trying to crack it in the US at this point as well but the UK took off for us because the co-founder of the firm wanted to go on sabbatical and sort of went away for a year and travelled the world and then wanted to live in the UK. So we thought we'd take the opportunity of him wanting to live in the UK for him to start scouting around and see what the market was like and to see what opportunities there were. So we took the opportunity to think, "Well, if he's overseas he can start looking for some opportunities over there" (Case F).

The joint founder used this opportunity to encourage his colleague to assess the UK market for business opportunities and to build client contacts in the industry. This happened very quickly, leading to a WOS sales office being set up in London, initially supported by revenue from the home office.

We wanted to see where we could take the product and the reason why he went to the UK is because he wanted to live in the UK ...It wasn't necessarily this strategy, "Let's hit the UK, then the US then whatever". ..we were dealing with Hoyts here in Australia and one of the people who we were pitching to here went over to the UK and worked for a chain of cinemas in the UK and she saw the product here and as it so happens, when she went back to the UK it was almost about the same time that D., who was the co-founder, ended up in the UK. And she rang me and said, "Look we want to use the 
product over here" and I said, "Well it just so happens we are actually in the UK" That's what happened... I mean we were supported by the Australian business as well but once we had got a client we said, "Well we do have a market over there so let's try and scout a bit more"! (Case F).

\section{Older Firms}

Offset fluctuations in demand: Downturns in the home market justify seeking foreign locations that can be used to offset fluctuations in demand. While we observe Asia as a preferred, geographically close international base for many larger older Australian professional service firms, such as engineering consultancies, according to Case W (supported by Case N), the UK provides a stepping stone into Europe and is also perceived as an ideal complementary European base from which to manage the industry's regular peaks and troughs in demand.

We had a fairly serious establishment in both Jakarta and Kuala Lumpur in the early 90s through to the mid 90s... during the down time in Australia when we had the very, very flat economic conditions in the early 90s...It was fundamental to us to try and maintain the staff that we had to pack our bags and look elsewhere for work because there just simply weren't the opportunities... We probably had our first,... enquiries in... 2001 and we entered the UK in 2002. Initially we set up an MAU with a local [UK] firm but then subsequently went from operating under a bit of an MAU to operating in a joint venture...if you look at the evolution of our business and I suppose when you go into a new market you learn a few lessons. We've learnt our few going up there [UK] but at the moment the UK has a very strong demand for our sorts of services. There's a lot construction activity up there... without a doubt a market for the services that we tend to offer (Case W).

Develop business back into the 'home' market: Similarly a small UK sales office can be set up to develop business back into the Australian market. This is frequently observed as a justification for market entry into the UK in the initial phase. However, after a number of years, described as the post-entry phase, we also observe how full commitment to the market in the form of a WOS (with permanent staff located in the UK) can provide a greater presence and credibility and thus enable development of a local customer base. According to Case $S$ (supported by Cases $O, T$ and $X$ ), the historical connections between the UK and Australia, and close cultural similarities, are frequently observed as primary motivations for initial entry into the UK over other Western markets in Europe. 
In the early stages the intention was to attract work and instructions and clients back into the firm in Australia. Not necessarily to do the work in London and to build a local practicing base in London. But after four or five years of seconding single partners over at the London office the firm decided the office had become a permanent feature of the firm's network if you like, and that therefore they needed somebody in London effectively more permanently...they...employed [me as a] lawyer, made me a senior associate fairly quickly just to give me some status because as soon as I joined, the partner went back to Australia and I was running the office by myself (Case S).

This also creates a lucrative opportunity to provide services for Australian MNEs entering the UK and European region. Thus, inward and outward business (Bjorkman, 1997) can be developed, and this is frequently used to build a client base in the home base from the UK office for professional services, such as legal.

Regulatory environment: Changes in the home market regulatory environment can also pave the way for Australian MNEs to rethink their skills and capabilities and subsequently move into overseas markets such as the UK, offering fewer barriers to tax restructuring, as revealed in Case $O$.

It's (UK entity) much bigger and established and independent but it still kind of links back to Australia. On the other side, the leasing structured side I think... the opportunity, the idea that we could transport these ideas and in some ways Australia was quite developed getting into other countries, partly I think the government had tightened... or changed the laws and quite a rigorous tax regime... in those days Australia was a harder place...there was a kind of negative push and also Australia tried to privatize things more quickly so the firm (bank) was well placed when we came later for the infrastructure side to have been more experienced than everybody else that was dealing with the transfer of government private sector (Case O).

Thus, we observe, push strategies as a major motivation for larger professional service firms, for example, in Case $O$, in the finance and investment sectors, and this is supported for other sectors including management software and hardware, commercial legal services, tertiary education and financial services (Cases $Q, S, T$ and $U$ ), for selecting culturally similar markets that offer institutional advantages over the home market, such as flexible taxation systems. For example, changes to the regulatory environment in the mid 1980s, drove Australian firms to seek out overseas markets offering more flexibility on financial/taxation factors influencing their company structures. 
Source of connections: The UK is perceived as an ideal base for larger professional services to connect to nearby European, English-speaking markets, such as Ireland, (supported by Cases $O, Q, R, S, T, U, W$ and $X$ ) as well as a useful source of connections into the ME, says Case N.

At the moment the main areas... the UK does occasionally reach into projects in Ireland. It's not consistent but we are looking at projects probably on and off every six months or so in Ireland...it's also looking at a project at the moment in Gibraltar out of the UK, which is a bit different...other areas of current interest are particularly United Arab Emirates...includes both the Dubai...and Abu Dhabi area at the moment... have project opportunities that we're working on in both...places (Case $N)$.

The ME, which has a long historic connection to the UK as well as Australia, and an Englishspeaking focus, provides many opportunities for newer arrivals for market entry and client building.

The UK, to a certain degree, was a springboard into some of the opportunities that we've been able to exploit in the Middle East, for example... strong, British company ties to certain operations that go on in the Middle East...led to our first really big project in Dubai, ...through a UK construction contractor - asked us to do value engineering through our office in London...subsequently led to us being successful and winning the project with that contractor and then redesigning and redocumenting the [next] stage... in Dubai. Most of which... ended up being documented in Brisbane but the opportunity was effectively for that project and that relationship spurned from the UK initially (Case N).

International experience: Some Australian MNEs perceive increasing international competition in the home market as exerting pressure on them to expand offshore, despite a large market share. According to Case $N$ (supported by $O, R, S, T, U, W$ and $X$ ), home-based clients are making it increasingly clear that they expect international experience, not just local experience, from larger, Australian professional service MNEs if they are to continue to be taken seriously domestically.

Electronic platform is easier, quicker and cheaper: We observe real interest in the UK as a preferred market for larger, innovative and high-tech manufacturers, largely because clients wanting to take up the technology and innovation require a suitable electronic platform, as suggested by Case $P$ (supported by Cases $M, Q$ and $V$ ). To be able to use English in the 
adaptation of the electronic platform is easier, quicker and cheaper. Thus, there is a preference for English-speaking markets that offer sizeable growth. We observe that these larger MNEs are very aware of how much adaptation is required for each client, especially if they are government or semi-government clients.

It needs to be purpose built for them... adapted. But it also needs to fit within their electronic or IT environment. What systems do they use? Do they use Windows-based? What sort?... So the French are very interested in it but...have different keyboards... a French Windows operating system...there were some French-related issues in Canada. But basically what I call the standard Anglo Saxon countries - the States, Canada, Australia, UK, New Zealand - in governmental management terms, there are strong similarities. Different things in the States in terms of scale and muscularity (Case P).

Preferred markets are Canada and NZ and, to a lesser extent, the US as it has different systems in place, which slows the introduction and buying process, suggested by Case $P$.

Opportunistic: Opportunistic motivations are supported by all cases, and illustrated by Case $V$.

About 18 years ago, we had an enquiry from an Englishman who wanted to do something...in the UK market. So we saw an opportunity where we thought, we are shutting down the US; we have got all this machinery... got into discussions with the NDC... and the decision was made that we could ship some of the equipment to the UK and start-up with - in relative terms - little capital injection because we had already paid for it. And that is really how the UK operation started! (Case V).

Following a failed business and winding up of a MNE's activities in another foreign market, a culturally proximate market can provide resources for an alternative, high growth market.

\section{Summary of Findings}

Table 1a summarises the particular elements (themes and sub-themes) as a comprehensive set of formative indicators, which explain the reasons why, initially, firms (born-globals and older) access culturally proximate markets, where the expectation is that it will be easier to do business and highlights whether their behaviour is 'reactive' or 'proactive'. Reactive behaviour is consistent with a traditional Uppsala (Johanson \& Wiedersheim-Paul 1975; Johanson \& Vahlne 1977) approach to early internationalisation, as the firm develops experience. These concepts have been detailed in the literature review in the 
section, Proactive or Reactive Behaviour, and summarised briefly below. Table $1 \mathrm{~b}$ provides the same summary for experiential knowledge ('international' or 'technological') indicators. These concepts were previously detailed in the literature review in the sections, Level of International Knowledge, and Level of Technological Knowledge, and again summarised below. As a process of re-reading the literature and revisiting the data from the multiple cases, data were sorted into those that related to 'reactive' or 'proactive' behaviour (Table 1a) and 'international' and 'technological' knowledge (Table 1b) based on the definitions provided in Nordman and Melen's (2008) study of born-globals.

Relying on the data analysis process a number of elements emerged, which when mapped, captured a comprehensive set of formative indicators for proactive or reactive decision-making. Guided by Nordman and Melen's (2008) definitions, elements were coded as reactive, as the discovery of opportunity cannot be planned, and thus are the consequence of chance, as it cannot be controlled. Thus, reactive refers to the 'ongoing interactions with individuals in a specific foreign market'. The discovery of new opportunities can be referred to as proactive, if the concepts related more to 'search activities', as the activities performed by born-globals are those which address knowing what is missing and where they think that knowledge can be found. Importantly, these types of activities can be planned in advance. These activities are different from opportunities that are discovered within ongoing foreign market activities, which are a consequence of chance, rather than planned activities.

Nordman and Melen (2008) argued that international knowledge is about managing various relationships with foreign partners, and is experiential knowledge of business activities across international boundaries. They make a clear distinction between these two types of knowledge for born-globals. Given these firms are new, and lack organisational history, the founder's or manager's knowledge of foreign markets is very important. Thus, individual-level knowledge precedes firm-level knowledge. International knowledge is 
broader than technological knowledge as a concept, and includes specific international industry and marketing experience pertinent to the manager's sector. The managers working in these firms possess highly sophisticated and relevant technological knowledge. Both types of knowledge will influence the firm's ability to discover and exploit new opportunities. Relying upon Nordman and Melen (2008), we defined technological knowledge as experiential because they argued it is about the technology upon which the products/processes are developed. It is devoid of business knowledge and is about sophisticated technical issues relevant to the born-global. Thus, elements were coded as international knowledge if they related to 'managing various relationships with foreign partners' or as technological knowledge if they related to 'technology upon which the products/processes are developed and produced'. A summary of the coding process for the formative indicators is found below in Tables $1 \mathrm{a}$ and $1 \mathrm{~b}$.

\section{Insert Table 1a here \\ Insert Table $1 \mathrm{~b}$ here}

In addition, Table 2 provides a numerical aggregate for reactive and proactive behaviour and experimental (international and technological) knowledge. To develop the aggregates, the number of occurrences of each theme was counted. Where there were multiple sub-themes, only the sub-themes were counted and not the main theme to avoid double counting. The aggregates in Table 2 are designed to provide a simple and comprehensive summary of the differences across the formative indicators for both born-globals and older firms for comparative purposes. What is significant and new about our study is that we extend earlier research by explaining how managers from both types of firms behave and use knowledge, initially, when accessing a culturally proximate market. We contribute to both the 
internationalisation and born-global theories by comprehensively revealing, within each firm type, different combinations of elements and dimensions (themes and sub-themes), which are being emphasised. For the first time, our study is able to provide evidence, that despite similar aggregates for born-globals and older firms across many of the themes, there are distinct differences between the firm types about how they behave and why they do so in their early internationalisation process. For example, while both firm types use similar levels of international knowledge, within the element of 'shared language/culture', born-globals rely on both dimensions (familiarity \& preferred location), and older firms utilise none. For 'technological knowledge', within the element of 'familiar regulatory environment (allows rapid entry)', while born-globals rely on both 'established tax treaty' and 'few barriers to tax restructuring' in the culturally proximate market, older firms are only relying on one element, the latter.

\section{Insert Table 2 here}

\section{DISCUSSION}

The findings explain why some born-global and older firms have a propensity to seek out culturally proximate markets for their initial investments or to leverage networks and knowledge of culturally proximate markets if they choose to enter into non-culturally proximate markets. While the numerical aggregates for the formative indicators (which have emerged from the analysis and are detailed in Tables $1 \mathrm{a}$ and $1 \mathrm{~b}$ and summarised in Table 2) with respect to proactive or reactive approaches and experiential knowledge (technological and international) when entering a culturally proximate market are remarkably similar overall, the areas of emphasis differ quite markedly between born-global and older firms. In particular, the technological knowledge dimension is nearly 3 times more important for bornglobal (22/26) than for older firms (8/26), as illustrated numerically in Table 2. 
Both types of firms mentioned a similar number of dimensions for international knowledge (9/13 for born-globals and 8/13 for older firms), (which refers to experiential knowledge about conducting business within an international setting), but referred to different issues. For example, managers in both born-globals and older firms spoke of "presence in a key culturally proximate market", namely the UK, which "provides credibility for links into other non-culturally proximate markets like the Central and Western Europe, CEE and the ME". Only born-globals referred to the advantage of a "shared language/culture" in the UK with respect to providing "familiarity (easier market for initial entry into region than a nonEnglish speaking market)" and "preferred location for expatriates and their families". Only born-globals highlighted the advantage of the UK because of "the size of a large familiar market" as important in offering "local staff recruitment and from near non-culturally proximate markets", the "near market effects of technology", which "lead to "Western and CEE manufacturing and supply chain operations" and "more sympathetic government funding for innovation". Only larger older firms value "locating partners through acquisition in a culturally proximate market (UK) who have much experience in non-culturally familiar markets for both the Western and Eastern European regions", and "having domestic clients that desire to deal with suppliers with international experience".

Although both types of firms showed a favourable relationship between networks and technological knowledge, (which refers to experiential knowledge about the technology upon which the firm's producers are built), and early selection of culturally proximate markets, this was especially so with born-globals. It is evident that far greater emphasis is placed on technological knowledge by born-global than by older firms. In discussing the role of technological experience born-globals mention 22 of the 26 dimensions, while older firms mention only 8 . In developing the themes, both value a "familiar regulatory environment in a culturally similar market in having few barriers to tax restructuring" though only born-globals 
mention the value of "an established tax treaty". Only born-globals mention the value of a "familiar legal system which allows rapid entry" because it "offers IP and copyright protection" and "offers product/process registration". Both refer to the importance of a "large familiar market for offering specialization (functions, products, processes), scale, being easier, quicker and cheaper", while only born-globals mention "offering very high earnings not available in the small domestic market", "multilingual skills", "opportunity for larger electronic platforms" and "synergies for supporting industries, such as advertising". Only older firms mention "offering diversity". Both discuss the "technological knowledge" available for "raising profiles" generally.

Only born-globals emphasise the UK for the "importance of a stepping stone market for control being maintained from a domestic base", "a stepping stone into CEE for lower costs, manufacturing support and entry into other parts of Europe", "base for managing exporting into the rest of Europe" and "new market effects of technology in providing bigger global brands" and "attracting supporting high-technology industries".

Finally, only born-globals emphasise "the lead market effects (technology), which provides a "sophisticated market supporting high readiness to adopt high tech products/processes" by local customers. This is important for born-globals, and unlike older firms emphasise this lead technology market provides an "easy initial market for establishing a much needed cash flow", where they can utilise their "first mover location for entering an emerging industry/sector". Only the born-globals emphasise the need for "good markets to take risks with innovative products", as the technology drives their rapid expansion.

The latter issues clearly suggest the problems which born-globals face with respect to technology relative to older firms and that their predominance in high-tech industries is likely to lead them to emphasise the importance of gaining further technical knowledge through their international ventures as suggested previously by Knight and Cavusgil (2005). 
Consistent with the KBV of the firm our findings suggest that born-globals are seeking both international and technical knowledge (Nordman \& Melen 2008). The findings demonstrate these firms are simultaneously considering opportunities and committing to avail themselves of these opportunities by acting to locate network partners leading to their internationalisation.

With respect to behaviour categorised as proactive, born-globals have 10 of the 12 dimensions while older firms have 7 . Both firm types choose a culturally proximate market because of "the opportunities to serve as a stepping stone or springboard to other near culturally proximate markets", "culturally familiar and convenient 'home base' in large overseas region" which is "a central location to other strategically important markets in Western Europe" generally, with born-globals citing more preference for "Northern Europe and lead markets outside of the UK". Both cite the value of proactively "expanding the customer base through opportunistic, 'have a go' activities”. Only born-globals demonstrate proactive behaviour in citing their reasons for moving to a culturally proximate market as "a stepping stone into non-culturally proximate markets". Older firms only use proactive behaviour in relation to "offsetting downturns in domestic markets" and "expanding the customer base through fishing (opportunity seeking)".

Both firms demonstrate the dimensions of reactive behaviour, which emphasises ongoing interactions between a firm and individuals in a specific foreign market, in their approach to culturally proximate markets, but in different ways, with born-globals emphasising 6/7 and older firms 2/7 dimensions. Born-globals are reactive in "expanding their customer base through "historical connections" by "following existing clients", and using "family" and "colleagues", and also through unplanned searches which implies "expanding the customer base through chance". 
Older firms emphasise reactive behaviour, by citing the value of "using culturally similar markets to develop business back in the domestic market". Both types of firms emphasise the value of the UK as a "stepping stone" to "develop ties for connections to other near culturally proximate markets".

Unlike earlier research arguing that firms can be either reactive or proactive (Nordman \& Melen 2008; Johanson \& Vahlne 2003; 2006), our findings demonstrate that both firm types are reactive and proactive and that proactiveness is not driven by high levels of international experience as the born-globals have limited experience. The findings are in accord with Freeman and Cavusgil (2007) who refer to flexible mindset (managerial orientation) with firms moving among various proactive and reactive states as part of the born-global's search and exploitation behaviour. Born-globals interest in proactively acquiring new knowledge and building absorptive capacity through stepping stones initially into "culturally proximate markets" and quickly moving to take advantage of "near market effects to other non-proximate markets" with the technological readiness, while also reactively "grasping established clients", and allowing for "chances opportunities" in their existing foreign market, allows them to maximise their high-tech, innovative nature through discovery and exploitation. Older firms, though, rely more on a traditional incremental approach to international success which does not have the same emphasis on pace and time.

Based on an analysis of our research data and extant literature, we develop the following concluding propositions:

Proposition 3: There is likely to be an association between the firm's networks and its international knowledge and the firm's early selection of culturally proximate markets in both born-globals and older firms.

Proposition 4: The relationship between the firm's networks and its technological knowledge and the firm's early selection of culturally proximate markets is more likely to be associated with born-globals than older firms.

Proposition 5: Born-globals are more likely to behave proactively than older firms, in initially seeking out technologically advanced, culturally proximate markets. 
Proposition 6: If the culturally proximate market does not offer a revenue stream (sales) soon after entry, born-globals are more likely to behave proactively than older firms.

We have used the data from our case studies to revise the introductory propositions by including the relevance of networks (customers, suppliers, competitors, government and educational institutions) and addressing the 'why' question for our concluding propositions by explaining the reason for them. Consequently, the rationale for Proposition 4 is that bornglobals lack international knowledge. The explanation for Propositions 5 is that born-globals have less financial resources and thus time to respond to opportunities as a reactive strategy. The explanation for Proposition 6 is that born-globals leverage technological knowledge and networks to move very quickly into nearby non-proximate markets because they lack financial resources.

\section{CONCLUSIONS}

Basing their research on the Uppsala model, Petersen et al. (2008) suggest that, when internationalising, firms limit the resources they are likely to commit to foreign markets based on 'maximum tolerable risk'. We suggest that born-globals' lack of international knowledge need not be an impediment to discovering and exploiting foreign market opportunities. We build theoretical understanding of born-globals, arguing that they do not have to rely on an incremental learning and reactive approach promoted by the Uppsala model (Johanson \& Vahlne 2003; 2006; 2009). Rather they depend on their technological knowledge and networks/contacts and will take a more proactive approach, being prepared to move rapidly from culturally proximate into culturally non-proximate markets and vice-versa, early in their evolution. We contend that this is logical behaviour for new entrants in highly competitive, knowledge intensive industries given they lack financial and human resources and 
organisational history. They need to maintain a constant revenue stream (sales) if they are to survive.

We contend that Petersen et al. (2008) do not address the entrepreneurial mindset of the managers of born-globals documented in earlier research as exhibiting proactive, innovative and risk-taking behaviour (Oviatt \& McDougall 1994), which leads them to seek out foreign partners who already have international experience (Freeman et al. 2006). As noted by Nordman and Melen (2008), what separates born-globals from traditional firms is their willingness to act quickly, presumably without all of the knowledge required for success of the foreign activity/venture. Barkema and Drogendijk (2007) suggest firms that internationalise in larger steps than those adopting an incremental approach, will have lower initial performance, but interestingly, through learning and experience, will increase performance in future expansion more so than traditional firms. We posit that the difference between the two types of firms is explained by the entrepreneurial approaches to discovery and exploitation by managers of born-globals, which enables them to learn quickly and 'access' or 'exploit' further opportunities for technological development and innovation necessary to sustain growth.

Earlier born-global research suggests reliance on high-tech, knowledge-intensive competitive capabilities, while older firms rely on their prior international experience. Our research suggests that born-globals do not follow an incremental approach to international expansion. Extending existing research, we argue that the reason some born-globals initially choose a culturally proximate market is that they can quickly move between proximate and non-proximate markets, by leveraging their networks. Building understanding of the knowledge development process, we contend that born-globals have advanced experiential knowledge, derived from technological expertise, (while older firms tend to rely on international knowledge). This supports their effectiveness in quickly discovering and 
exploiting opportunities, often in overseas locations. Contrary to research claiming that firms can be either reactive or proactive in internationalising, we expand on the Uppsala approach to internationalisation. We suggest that each type of firm demonstrates both reactive and proactive behaviour, but born-global firms reveal an entrepreneurial propensity perspective; relying more on proactive behaviour than their older counterparts.

\section{Managerial Implications}

This research has important implications for firms in managing the international process. Highlighting that cultural proximity is indeed a factor in determining early selection of foreign markets for firms which seek to minimise risk, we reinforce earlier studies arguing that born-globals rely on their technological knowledge in the absence of international experience. Born-globals need to recognise their limitations and leverage their strengths and capabilities not only by taking advantage of their technical-and-knowledge-intensive skills but also by developing and utilising networks with other newly internationalising firms, as well as building partnerships with older firms who have established networks and experience and with whom they can share their superior technical skills. There are important lessons for both types of firms, to be proactive and less risk-averse in managing their internationalisation in order to absorb new knowledge and grow their existing stock of knowledge in seeking out both culturally proximate and non-proximate markets, early in their expansion.

\section{Limitations and Issues for Future Research}

While this research provides rich data from multi-industry, multi-sized organisations of varying international experience, the study is limited in its theoretical generalisability. While we did achieve triangulation of data though accessing company documentation to support the interviewees' responses, we accept that having a single respondent from most 
firms is a limitation. Our research studied born-global and older firms at two ends of the spectrum of international experience, but there would also be value in exploring the mediumsized firms which have followed an incremental approach to internationalisation.

The issue of cultural proximity was addressed in this research because of the concerns raised in extant literature regarding inconsistent attitude as an influence on firm decisionmaking when entering overseas markets early in their internationalisation. For the firms in this study, selecting a culturally proximate market for FDI was important early in their international foray but as indicated in our findings for many different reasons. Some moved into near markets very quickly, which were usually culturally distant for born-globals. All the firms in this study were employing FDI and certainly the significance of the concept of cultural proximity has been criticised more recently, especially for FDI. In their revised internationalisation model, Johanson and Vahlne (2009) argue that it is 'outsidership', i.e. being outside the network that creates more uncertainty rather than psychic distance. We selected service and manufacturing B2B firms in this study to see if there were noticeable differences. We also chose large and small firms. However, no significant or emphasised differences for service vs manufacturing or large vs small firms emerged. Our focus was on comparing born-globals with older firms and we have detailed these differences closely. However, we suggest in future research studies these points of comparison, as well as business to business verses business to consumer warrant exploration. Finally, our research explores only Australian firms and the shorter history of internationalisation of these firms relative to firms in other Western, industrialised countries may have made them more likely to seek culturally proximate markets. In our study we have provided a theoretical and empirical explanation on the significance of a culturally proximate market to a born-global (new) and older firm involved in early internationalisation, consistent with the Uppsala model. Our method details a very typical market chosen initially by Australian firms, the UK, based 
primarily on the expectation that it is culturally proximate. How that explanation might differ in other culturally proximate markets is worth considering under future research. Thus, future research should consider a quantitative study with a large sample and a broader range of firm sizes from various countries with multiple organisational respondents. Such a quantitative study could test the concluding propositions developed in this study.

\section{REFERENCES}

Agndal, H. \& Chetty, S. (2007). The impact of relationships on changes in internationalization strategies in SME's. European Journal of Marketing, 41(11/12), 1449 1474.

Arenius, P. (2005). The psychic distance postulate revised: From market selection to speed of market penetration. Journal of International Entrepreneurship, 3 (2), 115-131.

Autio, E. (2005). Creative tension: The significance of Ben Oviatt's and Patricia McDougall's article 'Toward a theory of international new ventures'. Journal of International Business Studies, 36(1), 9-19.

Barney, J. (1991). Firm resources and sustained competitive advantage. Journal of Management, 17(1), 99-120.

Barkema, H.G. \& Drogendijk, R. (2007). Internationalising in small, incremental or larger steps?. Journal of International Business Studies, 38(7), 1132-1148.

Bell, J.H.J. (1995.) The internationalisation of small computer software firms. European Journal of Marketing, 29 (8), 60-75.

Bjorkman, I. \& Kock, S. (1997). Inward international activities in service firms - illustrated by three cases from the tourism industry, 8(5), 362-376.

Bouchikhi, H. (1993). A constructivist framework for understanding entrepreneurship performance. Organization Studies, 14, 549-570. 
Brewer, P.A. (2007). Operationalizing psychic distance: A revised approach. Journal of International Marketing, 15(1), 44-66.

Chetty, S. \& Campbell-Hunt, C. (2003). Paths to internationalisation among small-to-medium sized firms: A global versus regional approach. European Journal of Marketing, 37(5/6), 796823.

Chetty, S. \& Campbell-Hunt, C. (2004). A strategic approach to internationalization: A traditional versus a 'born-global' approach. Journal of International Marketing, 12(1), 57-81.

Chetty, S. \& Stangl, L. (Forthcoming, 2010). Internationalization and innovation in a network relationship context. European Journal of Marketing.

Crick, D. \& Spence, M. (2005). The internationalisation of 'high performing' UK high-tech SMEs: A study of planned and unplanned strategies. International Business Review, 14(2), 167-185.

Dubois, A. \& Gadde, L-E. (2002) Systematic combining: An abductive approach to case research. Journal of Business Research, 55, 553-560.

Eisenhardt, K.M. (1989). Building theories from case study research. Academy of Management Review, 14, 532-550.

Freeman, S., Edwards, R., \& Schroder, B. (2006). How smaller born-global firms use networks and alliances to overcome constraints to rapid internationalization. Journal of International Marketing, 14(3), 33-63.

Freeman, S. \& Cavusgil, S.T. (2007). Entrepreneurial strategies for accelerated internationalization of smaller born globals. Journal of International Marketing, 15(4), 1-40.

Freeman, S., Hutchings, K, Lazarius, M., \& Zyngier, S. (2010). A model of rapid knowledge development: The smaller born-global firm. International Business Review, 19(1), 70-84. 
Grant, R. M. (1996). Toward a knowledge-based theory of the firm. Strategic Management Journal, 17/Winter Special Issue, 109-133.

Hutzschenreuter, T. \& Voll, J.C. (2008). Performance effects of 'added cultural distance' in the path of international expansion: the case of German multinational enterprises. Journal of International Business Studies, 39(1), 53-71.

Johanson, J. \& Wiedersheim, P.F. (1975). The internationalization of the firm: Four Swedish cases. Journal of Management Studies, 12(3), 305-322.

Johanson, J. \& Vahlne, J-E. (1977). The internationalisation process of the firm - A model of knowledge development and increasing foreign market commitments. Journal of International Business Studies, 8(1), 25-34.

Johanson, J. \& Vahlne, J-E. (2003). Business relationship learning and commitment in the internationalization process. Journal of International Entrepreneurship, 1, 83-101.

Johanson, J. \& Vahlne, J-E. (2006). Commitment and opportunity development in the internationalization process: A note on the Uppsala internationalization process model. Management International Review, 46(2), 165-178.

Johanson, J. \& Vahlne, J-E. (2009). The Uppsala internationalization process model revisited: From liability of foreignness to liability of outsidership. Journal of International Business Studies, 40(9), 1411-1431.

Knight, G. A., \& Cavusgil, S. T. (1996), The born-global firm: A Challenge to traditional internationalization theory. Advances in International Marketing, 8, 11-26.

Knight, .G.A. \& Cavusgil, S.T. (2004). Innovation organizational capabilities and the bornglobal firm. Journal of International Business Studies, 35(2), 124-141.

Knight, G.A. \& Cavusgil, S.T. (2005). A taxonomy of born-global firms. Management International Review, 45(3), 15-35. 
Luostarinen, R., \& Gabrielsson, M. (2006). Globalization and marketing strategies of born globals in SMOPECs. Thunderbird International Business Review, 48(6), 773-801.

Madsen, T. K., \& Servais, P. (1997). The internationalization of born globals: An evolutionary process? International Business Review, 6(6), 561-583.

Majkard, A. \& Sharma, D.D. (1998.) Client-following and market seeking strategies in the internationalisation of service firms. Journal of Business-to Business Marketing 4 (3), 1-41.

McDougall, P. and Oviatt, B. (2000). International entrepreneurship: The intersection of two research paths. Academy of management Journal, 43(5), 902-906.

McDougall, P. P., Shane, S., \& Oviatt, B. M. (1994). Explaining the formation of international new ventures: the limits of theories from international business research. Journal of Business Venturing, 9, 469-487.

McKinsey, \& Co., (1993). Emerging Exporters. Australia's High Value-added Manufacturing Exporters. Melbourne: McKinsey and Company and the Australian Manufacturing Council.

Miles, M. B. \& Huberman, A. M. (1994). Qualitative Data Analysis: An Expanded Sourcebook, $2^{\text {nd }}$. Edition. Thousand Oaks: Sage.

Moen, O., \& Servais, P. 2002. Born global or gradual global? Examining the export behavior of small and medium-sized enterprises. Journal of International Marketing, 10(3), 49-72.

Nordman, E.R. \& Melen, S. (2008). The impact of different kinds of knowledge for the internationalization process of born globals in the biotech business. Journal of World Business, 43(2), 171-185.

Oviatt, B.M. \& McDougall, P. P. (1994). Toward a theory of international new ventures. Journal of International Business Studies, 25(1), 45-64.

Oviatt, B. M., \& McDougall, P. P. (1997). Challenges for internationalization process theory: The case of new ventures. Management International Review, 37(2): 85-99. 
Oviatt, B. M., \& McDougall, P. P. (2005). Defining international entrepreneurship and modeling the speed of internationalization. Entrepreneurship: Theory \& Practice, 29(5), 537553.

Penrose, E.T. (1959), The theory of the growth of the firm. Oxford: Blackwell.

Petersen, B., Pedersen, T., \& Lyles, M.A. (2008). Closing gaps in foreign markets. Journal of International Business Studies, 39, 1097-113.

Rialp, A., Rialp, J. \&, Knight, G. (2005). The phenomenon of early internationalizing firms: What do we know after a decade (1993-2003) of scientific enquiry? International Business Review, 14, 147-166.

Reid, S.D. (1983). Managerial and firm influences on export behaviour. Journal of the Academy of Marketing Science, 11(3), 323-332.

Schweizer, L. (2005). Organizational integration of acquired biotechnology companies into pharmaceutical companies: The need for a hybrid approach. Academy of Management Journal, 48(6), 1051-1074.

Sekaran, U. (2000). Research Methods for Business. $3^{\text {rd }}$ edition. New York: John Wiley.

Servais, P., Madsen, T. K., \& Rasmussen, E. S. (2007). Small manufacturing firm's involvement in international e-business activities. Advances in International Marketing, 17, 297-317.

Sharma, S.D.D. \& Blomstermo, A (2003). The internationalization process of born globals: A network view. International Business Review, 12(6): 739-753.

Strauss, A. \& Corbin, J. (1990). Basics of Qualitative Research: Grounded Theory Procedures and Techniques. Newbury Park, California: Sage.

Yin, R. K. (2003). Case Study Research: Design and Methods. Newbury Park, California: Sage Publications. 
Zahra, S. A., Ireland, D. R., \& Hitt, M. A. (2000). International expansion by new venture firms: international diversity, mode of market entry, technological learning and performance. Academy of Management Journal, 43(5): 925-950. 


\section{TABLE 1A: PROACTIVE VERSUS REACTIVE BEHAVIOUR}

Reasons why firms initially access culturally proximate markets

\section{Proactive versus reactive behaviour}

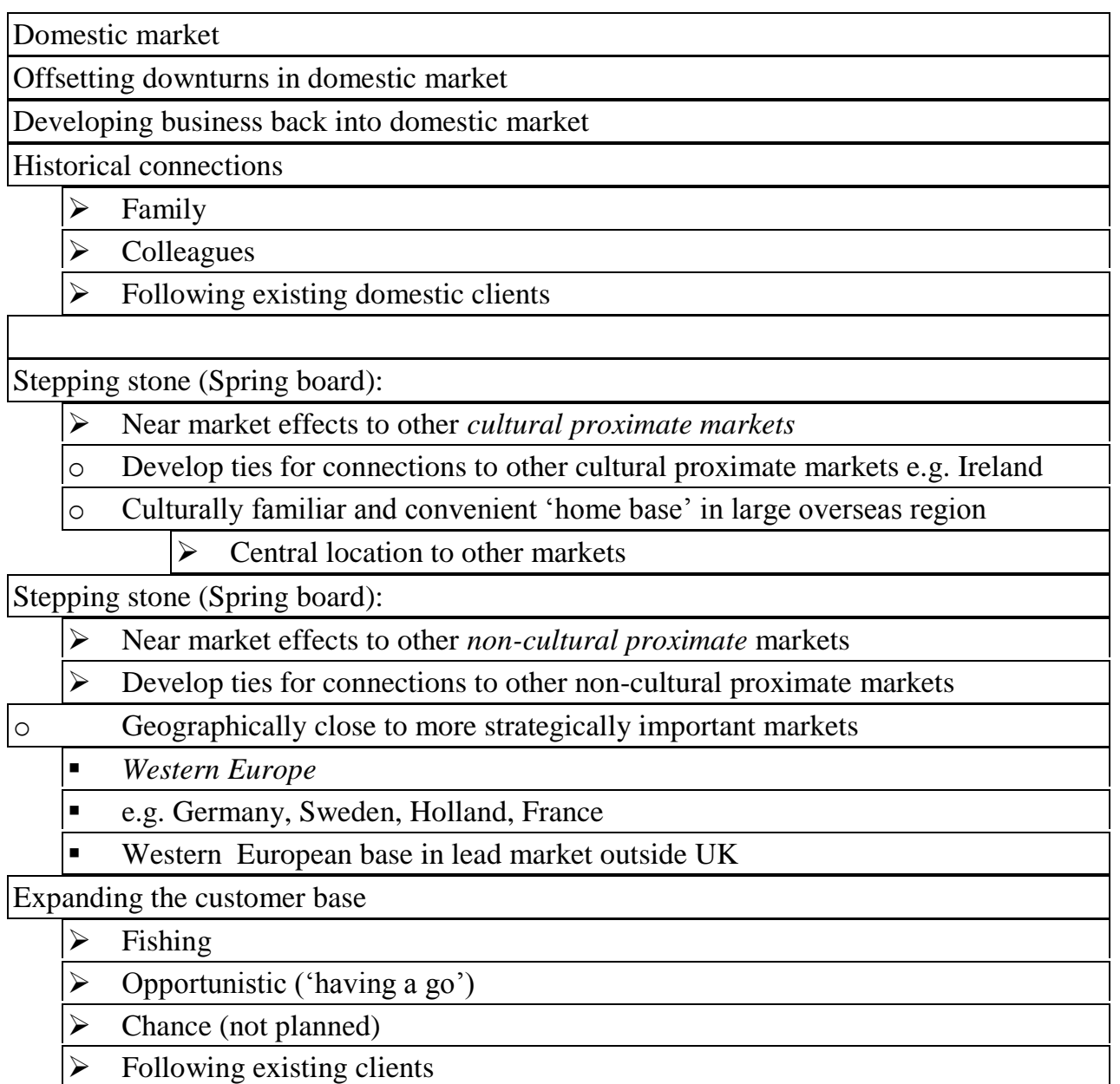
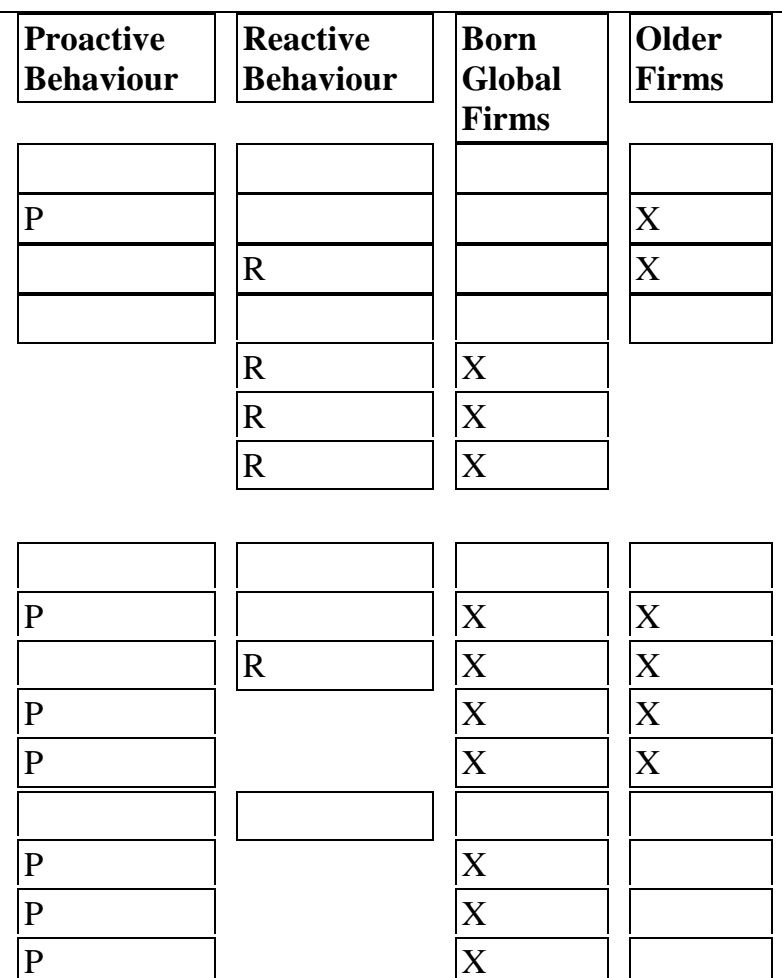

$\mathrm{P}$

$\mathrm{P}$

$\mathrm{P}$

$\mathrm{P}$

$\mathrm{P}$

$\mathrm{P}$
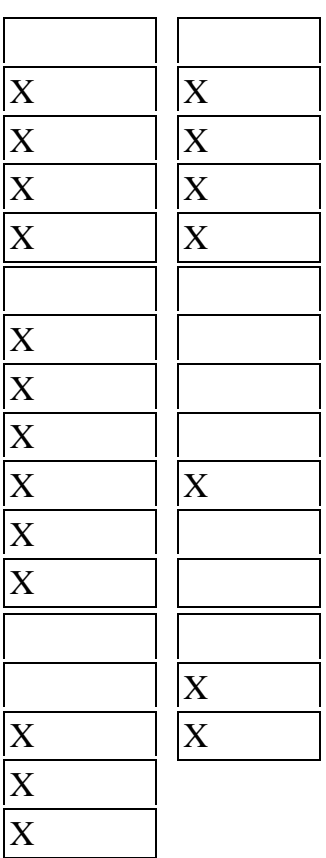
TABLE 1B: INTERNATIONAL KNOWLEDGE VERSUS TECHNOLOGICAL KNOWLEDGE

Reasons why firms initially access culturally proximate markets

- International versus technological knowledge

Shared language/culture

$>$ Familiarity (easier market for initial entry into region than a non-English speaking market)

$>$ Preferred location for expatriates and their families

Familiar legal system (allows rapid entry)

$>$ Offering IP and copyright protection

$>$ Offering product/process registration

Familiar regulatory environment (allows rapid entry)

$>$ Established tax treaty

$>$ Few barriers to tax restructuring

Initial phase of entry - control maintained from domestic market

Stepping stone (Spring board):

o Geographically close to more strategically important markets

- Central and Western Europe (CEE)

- lower costs

- location used to support manufacturing

- base for managing exporting into rest of Europe

Presence in key culturally proximate market in region to support credibility into other non-cultural proximate markets

- Central and Western Europe

- CEE

- Middle East

$>$ Acquisition route for easy entry

○ Locate partners through acquisition in cultural proximate market who have much experience in non-cultural proximate markets:

- Western European region

- Eastern European region

Domestic clients desire to deal with suppliers that have international experience

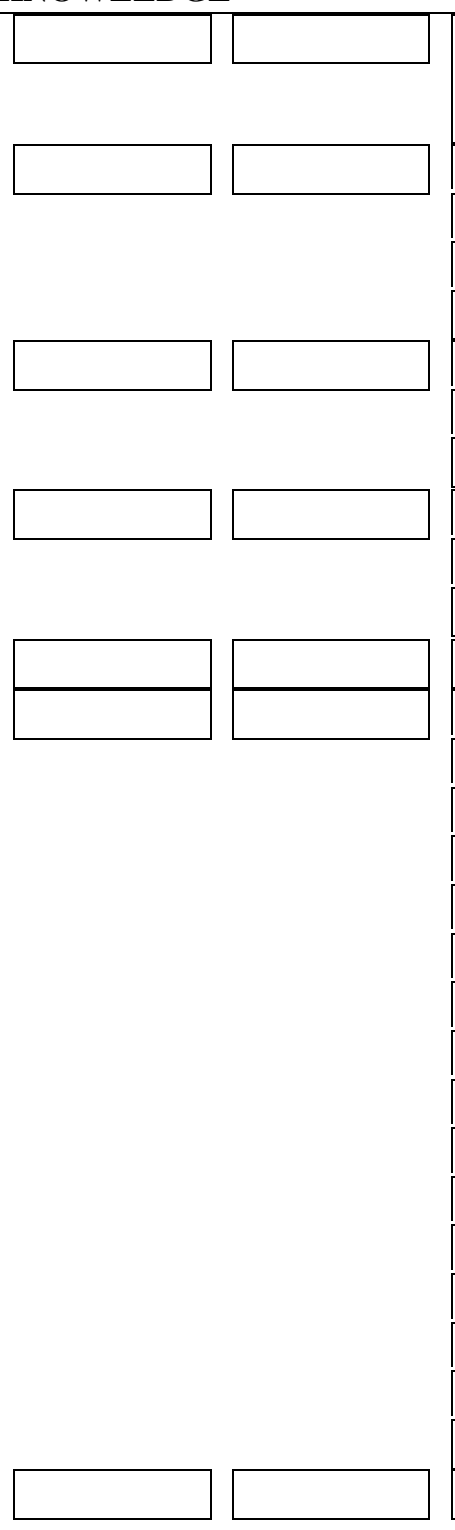

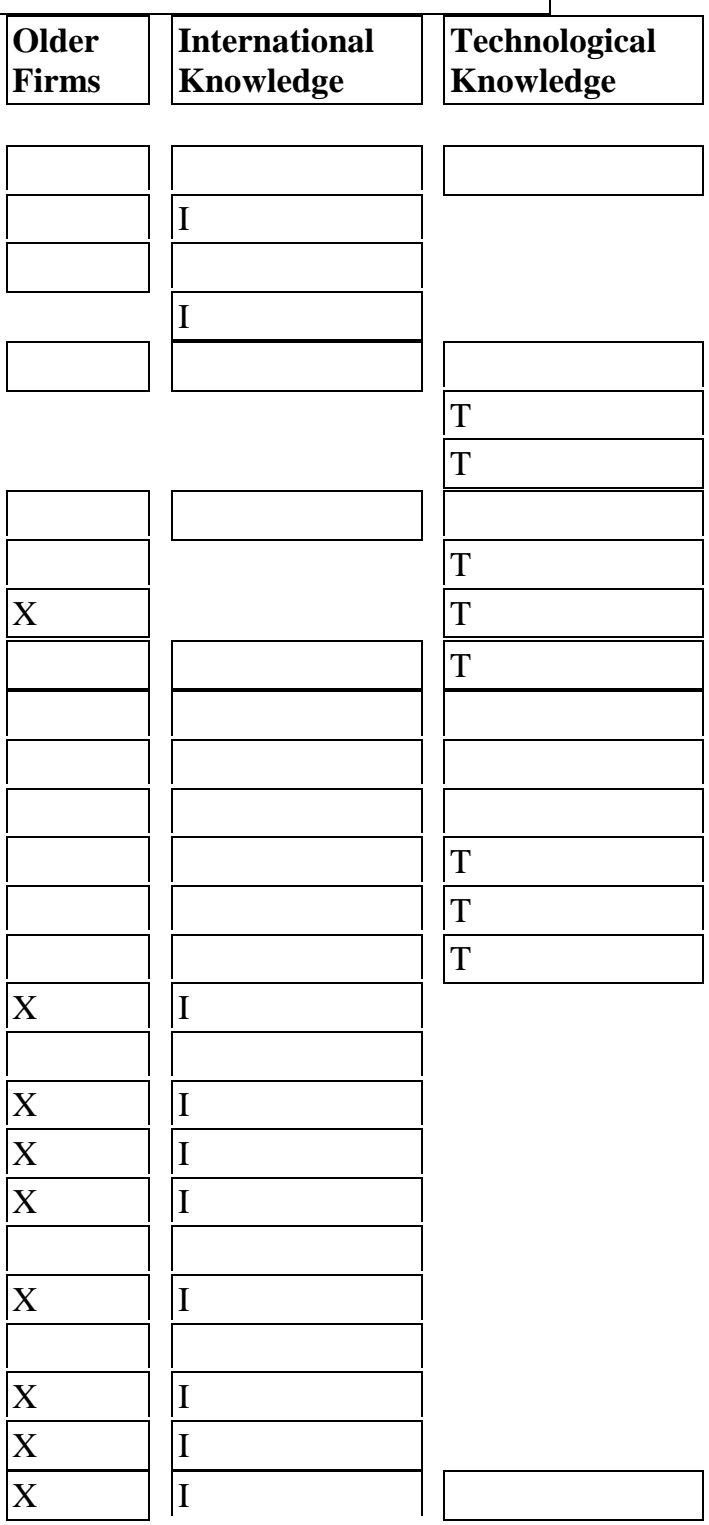




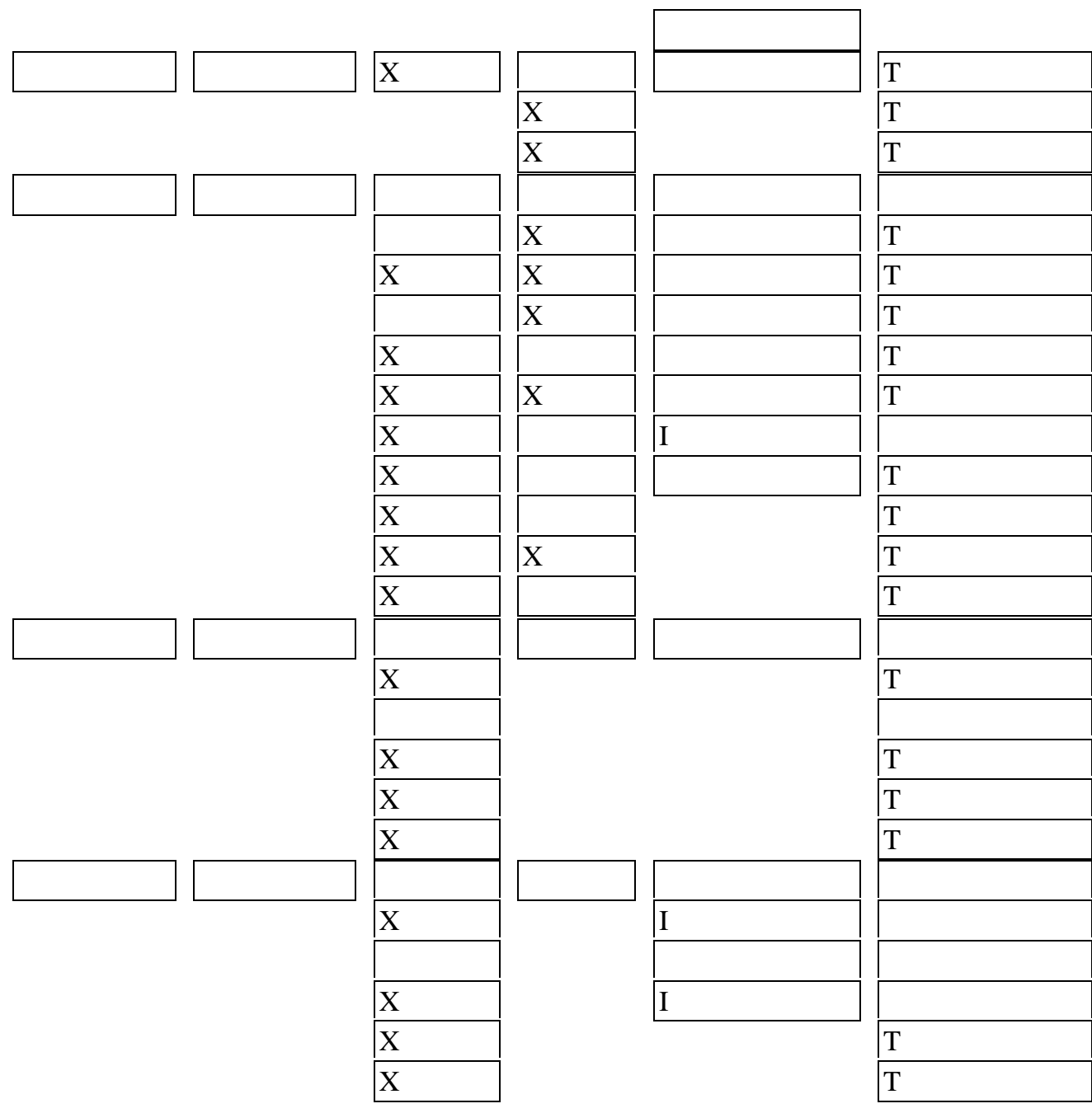

$>$ International branding and credibility

Large familiar market (size)

$>$ Offering diversity

$>$ Offering specialization (functions, products, processes)

$>$ Offering sufficient sales to offset high R\&D costs

$>$ Offering very high earnings not available in small domestic market

$>$ Offering scale

$>$ Offering local staff recruitment and from near non-culturally proximate markets

- Offering multilingual skills

$>$ Offering opportunity for larger electronic platforms

- Easier, quicker and cheaper

- Synergies related to supporting industries (e.g. advertising)

Lead market effects (technology)

> Sophisticated market supporting high readiness to adopt high tech products/processes

$>$ Easy initial market for establishing much needed case flow

$>$ First mover location for entering an emerging industry/sector

$>$ Good markets to take risks with innovative products

Near market effects (technology)

$>$ Lead to Western and Central and Eastern Europe (CEE) manufacturing and supply chain operations

- more sympathetic attitude from govt funding for innovative products

o bigger global brands present making it attractive for manufacturing

- attracts supporting high-technology industries (synergies)

$$
\text { (1) }
$$


TABLE 2: NUMERICAL AGGREGATES FOR PROACTIVE AND REACTIVE BEHAVIOUR AND INTERNATIONAL AND TECHNOLOGICAL KNOWLEDGE

\begin{tabular}{|c|c|c|c|}
\hline Proactive & Reactive & International & Technological \\
\hline Born-Global & Born-Global & Born-Global & Born-Global \\
\hline $10 / 12$ & $6 / 7$ & $9 / 13$ & $22 / 26$ \\
\hline Older Firms & Older Firms & Older Firms & Older Firms \\
\hline $7 / 12$ & $2 / 7$ & $8 / 13$ & $8 / 26$ \\
\hline
\end{tabular}




\section{APPENDIX A: SUMMARY OF DATA FROM BORN-GLOBAL FIRMS}

\section{Case Industry and Size}

A Venture Capitalist in Medical Technologies - small professional service

B Software/ hardware digital communication - Large service firm

C Medical Devices

- Large manufacturing firm

D Medical Devices

- Large manufacturing firm

E Resin Technology - Small Manufacturing firm

Digital Communication \& Learning

Cross Border Funds Management - Small Professional Service Firm

Project Management IT Platform - Construction Industry - Medium

Manufacturing \& Professional Services

\section{Founded Sales (past 12 months)}

2006

$1999 \quad 52 \%$ R growth in 2006

$40 \%$ - UK

1983 Sales: $17 \%$ - Asia; $38 \%$ - Americas Global - \$500M

1989 1. Global market capital - \$US 3.5B

2. $97 \% \mathrm{R}$ from exports

2002

2005

$30 \% \mathrm{R}-\mathrm{UK}$

$90 \%$ - UK. $10 \%$ - Aust

$100 \%$ per annum
Year UK Entry

2006

2002

1984

1992

2003

2003

2005

2003 
APPENDIX B: SUMMARY OF DATA FROM OLDER FIRMS

\begin{tabular}{|c|c|}
\hline Case & Industry and Size \\
\hline M & Oxide Fuels - Large Manufacturing firm \\
\hline $\mathrm{N}$ & Architectural \& Engineering Design - Large Professional Services \\
\hline $\mathrm{O}$ & Investment Banking - Large professional service \\
\hline $\mathrm{P}$ & $\begin{array}{l}\text { Software development in Scheduling/ Planning }- \text { SME } \\
\text { manufacturing \& professional service }\end{array}$ \\
\hline Q & $\begin{array}{l}\text { Management software \& hardware - Medium manufacturing \& } \\
\text { professional service }\end{array}$ \\
\hline $\mathrm{R}$ & $\begin{array}{l}\text { Cross-border Capital \& Assets Sales - Large Professional Services - } \\
\text { merger with old UK firm }\end{array}$ \\
\hline S & Commercial Law - Large professional service \\
\hline $\mathrm{T}$ & Tertiary Education - Large Professional Services \\
\hline $\mathrm{U}$ & Financial Services - wholesale - Large professional service \\
\hline $\mathrm{V}$ & $\begin{array}{l}\text { Residential \& Commercial Access Products - Large manufacturing } \\
\text { firm }\end{array}$ \\
\hline $\mathrm{W}$ & $\begin{array}{l}\text { Structural \& Civil Engineering - Large manufacturing professional } \\
\text { service }\end{array}$ \\
\hline $\mathrm{X}$ & Payroll and HR Software - Medium Professional Service Firm \\
\hline
\end{tabular}

Founded

1992

1927

1982

1993

1985

1999

1827

1958

$1800 \mathrm{~s}$

1942

1982

1983
Year UK Entry

2005

2006

1989

2001

1999

1999

1974

2000

1853

1989

2002

1991 
APPENDIX C: SUMMARY OF HISTORY OF CASE STUDY ORGANISATIONS

\begin{tabular}{|c|c|c|c|c|c|c|c|}
\hline Case & $\begin{array}{l}\text { Year } \\
\text { UK } \\
\text { Entry }\end{array}$ & 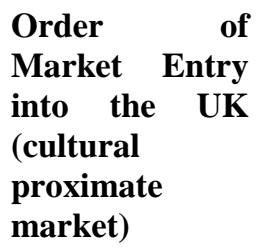 & 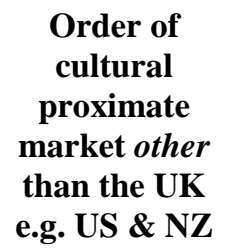 & First Market Entered & $\begin{array}{l}\text { Initial and } \\
\text { Subsequent } \\
\text { Mode of Entry }\end{array}$ & $\begin{array}{l}\text { No of Employees in } \\
\text { Australia and UK \& } \\
\text { Global Desire for more } \\
\text { staff in UK (Repeat } \\
\text { Investment Objective) }\end{array}$ & $\begin{array}{l}\text { Title } \\
\text { Interviewee }\end{array}$ \\
\hline A & 2006 & 2 & & $\begin{array}{l}\text { Germany } \\
\text { UK - 2nd }\end{array}$ & WOS & $\begin{array}{l}\text { Desire }-40 \% \text { more tech } \& \\
\text { sales staff }-1-3 \text { yrs }\end{array}$ & 1. CEO \\
\hline B & 2002 & 1 & & $\begin{array}{l}\text { UK } \\
5 \text { markets - Western - } \\
\text { e.g. US, Singapore }\end{array}$ & $\begin{array}{l}\text { 1. Acquisition } \\
\text { 2. Followed by } \\
\text { further } \\
\text { acquisitions }\end{array}$ & $\begin{array}{l}25 \text { - Aust } ; 60-\mathrm{UK} ; 160- \\
\text { Global } \\
\text { Desire - more tech \& sales } \\
\text { staff }-1-3 \text { yrs }\end{array}$ & $\begin{array}{l}\text { 1. Co-founder } \\
\text { (Bus/Mktg } \\
\text { Director) }\end{array}$ \\
\hline $\mathrm{C}$ & 1984 & 2 & 1 & $\begin{array}{l}\text { Germany \& US (same } \\
\text { time) } \\
\text { UK }-2^{\text {nd }} \\
90 \text { markets overall }\end{array}$ & $\begin{array}{l}\text { 1. WOS - } \\
\text { centralized } \\
\text { warehouse } \\
\text { 2. Functions to } \\
\text { service Europe }\end{array}$ & $\begin{array}{l}50-\text { UK } \\
300-\text { Europe } \\
1600-\text { Global } \\
\text { Desire - more tech \& sales } \\
\text { staff }-1-3 \text { yrs }\end{array}$ & 1. CEO \\
\hline $\mathrm{D}$ & 1992 & 2 & 1 & $\begin{array}{l}\text { US. } \\
\text { UK - 2nd } \\
\text { Nordic Cities } \\
\text { Germany \& France. } \\
72 \text { markets }\end{array}$ & WOS & $\begin{array}{l}2500-\text { Global } \\
\text { Desire }-20 \% \text { more tech \& } \\
\text { sales staff }-1-3 \text { yrs }\end{array}$ & $\begin{array}{l}\text { 1. Chief Ops Mgr } \\
\text { 2. Head - UK } \\
\text { Ops }\end{array}$ \\
\hline $\mathrm{E}$ & 2003 & 1 & & $\begin{array}{l}\text { UK. } \\
\text { Then quickly into } \\
\text { Germany \& CEE. }\end{array}$ & WOS. & $\begin{array}{l}8-\text { UK (now } 1 \text { ) } \\
\text { Moved } 7 \text { to Germany. } \\
45-\text { Aust }\end{array}$ & 1. CEO \\
\hline $\mathrm{F}$ & 2003 & 1 & & UK & WOS & $\begin{array}{l}45-\text { Aust; } 3-\mathrm{UK} ; 1-\mathrm{US} \\
\text { Desire }-20 \% \text { more tech \& } \\
\text { sales staff }-1-3 \text { yrs }\end{array}$ & 1. Co-Director \\
\hline G & 2005 & 1 & & UK. & Partnership. & $\begin{array}{l}4-\text { Global; } 3 \text { - Aust; } 1 \text { - } \\
\text { UK }\end{array}$ & 1. Dir - UK Ops. \\
\hline $\mathrm{H}$ & 2003 & 1 & & $\begin{array}{l}\text { UK. } \\
\text { then } 28 \text { offices in } 16 \\
\text { market. Focus on } \\
\text { Middle East }\end{array}$ & WOS & $\begin{array}{l}90-\text { Aust } ; 8-\mathrm{UK} ; 217- \\
\text { Global } \\
\text { Desire }-40 \% \text { more tech \& } \\
\text { sales staff }-1-3 \text { yrs }\end{array}$ & 1. Co-Director \\
\hline
\end{tabular}


UK.

Followed by Germany

within a year

Malaysia.

Followed

Philippines and NZ

and UK soon after. In

13 markets

$\mathrm{NZ}$, then in UK, 1. WOS

Scandinavia. Now in 2. Acquisition

all regions

UK \& Canada (same WOS

time)

3 other markets.

US and then UK

WOS

UK.

Now in 50 markets

1. Acquisition
2. JV - platform
in Western and

in Wes

UK.

Entered HK in late 80s.

Now Asia focused.

Partnership.

UK

3 ot WOSs

UK.

All regions

\section{WOS}

1. Joint Venture

Set up a WOS
Desire $-20 \%$ more tech \&

sales staff $-1-3$ yrs

Only 900 staff in 1999

1. $\mathrm{CEO}$

$800-$ UK

1. MD

2. Assoc. Dir.

60 - Aust; 2 - UK

1. MD

Desire $-20 \%$ more tech \&

ales staff $-1-3$ yrs

200 - Global; 103 - Aust; 1. CEO 46 - UK

56 - Nth America

1200 - Aust 1. Senior

Desire - more tech \& sales Consultant

staff -1-3 yrs (former

employee)

2. Head - Capita

Markets

8 partners - UK.; 280 1. Senior Partner partners

900 legal staff across Aust,

HK, China, Indone'ia, NZ

\& US.

Desire $-20 \%-1-3$ yrs

1. Strategic $45,000-$ global

Desire $-20 \%-1-3$ yrs

1. Gen Mgr Eur

$\&$ America
2 - UK

Decided to withdraw - late 2007

87 - UK

1. Office Mgr

WOS 
(overall head of

both regions)

V
W
X

1991
1

US

/S sites - Asia and

Europe including UK

UK.

Quick

Indonesia

Malaysia. 6 markets

NZ, then UK followed by SNG \& KL 3 years

ago.
WOS

censed othe

sites

1. MOU

firm.

2. JV after $1 \mathrm{y}$.

3. Acquisition

after 3 years

1. WOS.

2. HQ (moved to

UK)
380 - Global (former UK Mgr taff $-1-3$ yrs

240 - Aust

60 - UK

1. Group MD

Desire - more tech \& sales 1. MD (founder). staff $-1-3$ yrs. 